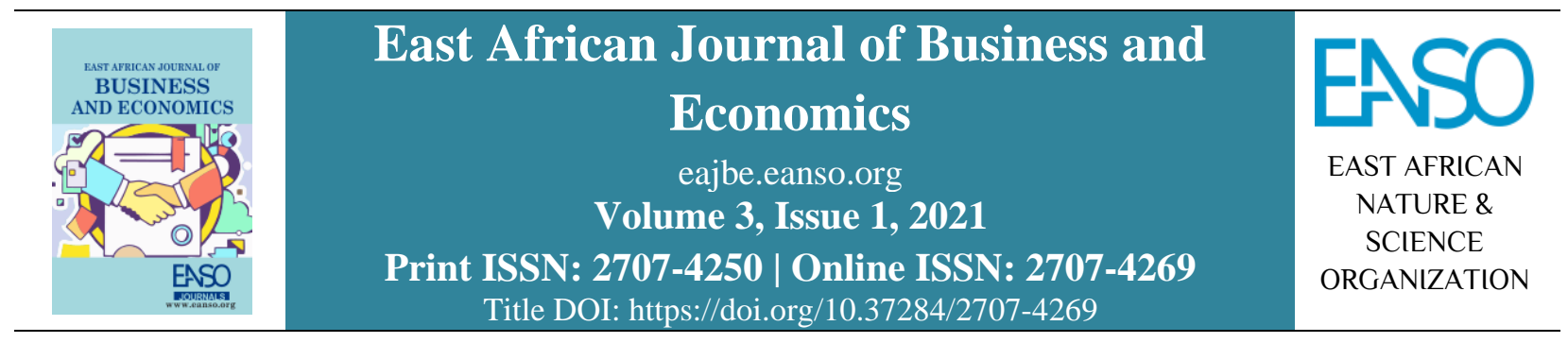

Original Article

\title{
Does the Incomplete Exchange Rate Pass-through Exist in Sudan?
}

\author{
Ahmed Abdu Allah Ibrahim, $P h D^{1} \&$ Mohamed Sharif Bashir, PhD \\ ${ }^{1}$ Al-Neelain University, P. O. Box 12702, Khartoum, Sudan. \\ ${ }^{2}$ Imam Mohammad Ibn Saud Islamic University, P. O. Box 5701, Riyadh 11432, Saudi Arabia. \\ * ORCID: https://orcid.org/0000-0001-5110-8503; Correspondence email: msharief@ hotmail.com.
}

Article DOI: https://doi.org/10.37284/eajbe.3.1.394

\section{Date Published: ABSTRACT}

28 August 2021 The purpose of this paper is to examine the nominal exchange rate pass-through to domestic prices in Sudan from 1978-2017. An autoregressive distributed lag

Keywords: (ARDL) approach to cointegration is employed. The analysis is based on impulse response functions (IRFs) and forecast error variance decompositions

Pass-Through, (FEVDs). The dynamics of the cointegrated system can be investigated via the Domestic Prices, variance decompositions and IRFs. The findings confirm that the degree of Exchange Rate, exchange rate pass-through in Sudan is incomplete, and the empirical results Autoregressive also show that the domestic price index is predominantly caused by foreign Distributed Lag, price in both the short and long runs, in addition to the import price index and the nominal exchange rate; the exchange rate shock has a negative effect on the

Sudan. domestic price. Furthermore, FEVDs analysis illustrates that the variation in domestic price is primarily determined by the import prices, while changes in the exchange rate are primarily determined by the exchange rate itself.

\section{APA CITATION}

Ibrahim,A. A. A., \& Bashir, M. S. (2021). Does the Incomplete Exchange Rate Pass-through Exist in Sudan?. East African Journal of Business and Economics, 3(1), 147-163. https://doi.org/10.37284/eajbe.3.1.394

\section{CHICAGO CITATION}

Ibrahim, Ahmed Abdu Allah, \& Mohamed Sharif Bashir. 2021. "Does the Incomplete Exchange Rate Pass-through Exist in Sudan?”. East African Journal of Business and Economics 3 (1), 147-163. https://doi.org/10.37284/eajbe.3.1.394.

\section{HARVARD CITATION}

Ibrahim, A. A. A., \& Bashir, M. S. (2021) "Does the Incomplete Exchange Rate Pass-through Exist in Sudan?”, East African Journal of Business and Economics, 3(1), pp. 147-163. doi: 10.37284/eajbe.3.1.394.

\section{IEEE CITATION}

A. A. A. Ibrahim, \& M. S. Bashir, "Does the Incomplete Exchange Rate Pass-through Exist in Sudan?", EAJBE, vol. 3, no. 1, pp. 147-163, Aug. 2021.

\section{MLA CITATION}

Ibrahim, Ahmed Abdu Allah, and Mohamed Sharif Bashir. "Does the Incomplete Exchange Rate Pass-through Exist in Sudan?". East African Journal of Business and Economics, Vol. 3, no. 1, Aug. 2021, pp. 147-163, doi:10.37284/eajbe.3.1.394 


\section{INTRODUCTION}

An important issue in international economics relates to the relationship between exchange rate movements and changes in the price of traded goods; this phenomenon is known as the exchange rate pass-through (ERPT). When there is depreciation to the rate of exchange of a domestic currency against foreign currencies, it causes an increase in inflation as a consequence of the passthrough effect (Isnowati \& Setiawan, 2017, p. 323). The ERPT is the percentage change in the import price due to a one percent change in the exchange rate between the importing and exporting country (Lott, 2013, p. 2). Numerous researchers have studied ERPT for a long time, and the topic only grows in importance as globalization takes over. As a result of the communication revolution, the whole world is becoming a single market, where consumers and producers can easily contact one another. Due to the elimination of capital controls, switch from fixed to floating exchange rate regimes, and the degree of openness - the greater the degree of openness, the larger the ERPT-ERPT has become increasingly important in developing and emerging market economies.

As explained by Yol (2010), the worst problem inherited by the government of Sudan in June 1989 was the malignant inflation; government expenditures rose dramatically while tax and other revenues dwindled, resulting in worsening budget deficits. The bulk of these deficits were financed through bank lending; this meant an accelerating domestic credit expansion, which, in turn, resulted in excessive monetary growth, the biggest proportion of the deficit-financed from a domestic source. In the period 1978-1991, numerous devaluation episodes were implemented to alleviate problems pertaining to the balance of payments deficits, domestic demand management, boosting agricultural sector production, and stabilizing the financial sector. Extreme measures came in February 1992, when the government, upon concluding an economic reform package of the structural adjustment programs with the IMF, embarked on the liberalization of the economy. In light of these policies, the exchange rate plummeted immediately; as a result of these devaluation episodes, the inflation rate skyrocketed to the peak of $122.5 \%$ in 1991 (Ibrahim \& Bashir, 2020).

The Sudanese pound has been devalued several times. The first time, in June 1978, the Sudanese pound was devalued by 25 percent from US $\$ 2.5$ to US $\$ 2$ for all transactions other than cotton. The rate for cotton was devalued from US \$2.87 to US \$2.5 (Hussain \& Thirlwall, 1984, p. 147). Then devaluations episodes went on. Sudan adopted the managed float exchange rate regime, mainly because of the unavailability of dollars at official prices, which led to the growth of black-market transactions. The huge upward trend of devaluations started from 1991 due to the implementation of economic liberalization and the advent of the Gulf War, which drastically reduced capital inflow to the country (Ibrahim, 2001, p. 71). After the 1990s, the economic liberalization policy was imposed in the country, and Sudan was increasingly open to international trade. As a country that adheres to an open economy, Sudan's economy is strongly affected by the exchange rate movements (Ibrahim \& Bashir, 2020).

The main objective of this paper is to investigate the impact of nominal ERPT changes in the domestic price level during the period 1978-2017. The remainder of the paper is organized as follows: Section 2 deals with literature review, Section 3 presents the analytical framework, Section 4 presents the empirical results of the study, and Section 5 concludes the study with key conclusions and policy recommendations.

\section{LITERATURE REVIEW}

The majority of literature searches on ERPT indicate industry- or product-specific studies. These studies examine the pass-through to import prices of various products or industries on the micro-level 
instead of concentrating on the effects of aggregate price measures. A smaller, however similarly essential, research area focuses on the macroeconomic ERPT influences on aggregate price indices (Bacchetta \& van Wincoop, 2003; Campa \& Goldberg, 2005; Takhtamanova, 2010).

However, the research conducted in this article looks at the macroeconomic level, and therefore, in this review of the literature, we will mainly emphasize on these aggregated studies.

McCarthy (2000) examines the ERPT on the aggregate level for a number of industrialized countries. His research results show that the transfer of exchange rates to consumer prices is moderate, which is positively correlated with a country's openness and exchange rate stability and fluctuations, and negatively correlated with exchange rate fluctuations.

Jasová et al., (2016) conducted a study on how ERPT to consumer price index (CPI) inflation has changed since the global financial crisis. They found that ERPT, in emerging economies, is declined after the financial crisis, while ERPT in developed economies has remained relatively low and stable over time. They showed that the declining pass-through in emerging economies is related to decreasing inflation. They also indicated that it is important to control for nonlinearities when assessing ERPT. These results hold for both shortrun and long-run pass-through and persist vigorously to extensive changes in the specifications.

Isnowati and Setiawan (2017) studied the relationship between exchange rate, import prices, national income, and inflation. The method employed for the analysis was structural vector autoregressive. An impulse response function and forecast error variance decompositions were performed to determine the impact of the exchange rate on import prices and national income. The result showed that the pass rate is incomplete.
Exchange rate shocks have a positive impact on import prices and a negative impact on national income, while the impact of inflation on import prices is negative.

Amoah and Meshach (2018) re-examined the ERPT speed and range of consumer prices in Ghana. Johansen's maximum likelihood method is used to evaluate various symmetric and asymmetric ERPT models. In particular, the ERPT model that is asymmetric in the direction and magnitude of exchange rate changes is evaluated. Their research results show that long-term effective nominal exchange rate depreciation will cause consumer prices to rise, but this is not statistically significant.

Helmy et al., (2018) examined the pass-through of exchange rate fluctuations to domestic prices in Egypt during the period 2003-2015. They revealed that the ERPT in Egypt was quite significant but incomplete and slow. Consumer prices are higher than any other price index. This should inhibit the transmission of currency shocks.

Pham (2019) examined the ERPT into inflation, in Vietnam, using a vector autoregression (VAR) model during the period 2008-2018. The key finding is that from the impulse response results, the transmission of exchange rate shocks to inflation is significant, and this is ERPT. In addition, the evidence from the decompositions of variance shows that the exchange rate is a major factor in explaining inflation fluctuations.

In regard to Sudan, the authors are unaware of any direct empirical work being conducted by using the cointegration approach. In the present paper, both consumer-price and import-price pass-through for Sudan are estimated.

\section{METHODOLOGY AND DATA SOURCES}

\section{Model Specification}

In the present paper, the model employed to estimate the degree of the ERPT is derived based on 
the law of one price (LOP). The LOP is the most prominent theoretical framework for explaining the ERPT phenomenon. The theory states that the same product is sold in the same currency at the same price in different countries (Goldberg \& Knetter, 1997; Campa \& Goldberg, 2005).

Under the condition of complete competition between domestic and international commodity markets and no trade barriers, the exchange rate is the price of similar commodities at home and abroad in the local currency; the prices in the two markets are expressed in the common currency, and for a well-defined tradable good, the case has to be:

$P=P^{*} E$

where $\mathrm{P}$ is the price of the good in the home country expressed in the country's home currency, proxy by Sudan's consumer price index and $P^{*}$ is the price of the good in the foreign country expressed in the country's foreign currency or represents the relevant index of foreign price, proxy by the consumer price index of Sudan's five major trading partners, namely Saudi Arabia, China, Japan, Germany, and United Kingdom, for the base year 1990.

The source of data of Sudan's major trading partners is the Direction of Trade Statistics various issues, and the source of their GDP as far as their consumer price index is concerned, are collected from International Financial Statistics various issues, both published by the International Monetary Fund (1980-2018).

$\mathrm{E}$ is the official nominal exchange rate between the home country and foreign country currencies. The source of the official nominal exchange rate data was collected from the Central Bank of Sudan.

Departures from the LOP occur when the exchange rate pass-through is incomplete.

$P^{\wedge}=P^{* \wedge}+E^{\wedge}$ where $\wedge$ denotes the proportional change. Passthrough is complete when $\frac{P^{\wedge}}{E^{\wedge}}=1 "$, or, $\frac{d p / p}{d E / E}=1$ (Dwyer et al., 1994).

This expression states that the price of an item should be the same in every country once adjusted for the exchange rate.

The domestic price pass-through equation to be estimated is in the form

$P_{t}=\alpha_{0}+\alpha_{1} E_{t}+\alpha_{2} P_{t}^{*}+\alpha_{3} M_{t}+\mu_{t}$

Where $\mathrm{M}$ is the import price index.

All the variables are in the index and logarithmic forms.

The coefficient of ERPT in Equation (3) is $\alpha_{1}$ is the coefficient of the nominal exchange rate, which is expected to produce a partial pass-through or if $0 \leq$ $\alpha_{1} \leq 1$. If $\alpha_{1}=1$, there is complete pass-through, and if $\alpha_{1}=0$, there is no pass-through.

If the time series variables of $P_{t}, E_{t}, P_{t}^{*}$ and $M_{t}$ have unit roots, we need to take the first difference of the variables in order to obtain stationary series. Thus, taking the first difference of the log of Equation (3) yields:

$$
\Delta P_{t}=\alpha_{0}+\alpha_{1} \Delta E_{t}+\alpha_{2} \Delta P_{t}^{*}+\alpha_{3} \Delta M_{t}+\mu_{t}
$$

\section{Method of Estimation}

The VAR approach to time series analysis has been adopted to investigate the pass-through of exchange rate fluctuations to import prices and domestic prices, involving cointegration analysis, an error correction model, impulse response functions, and variance decomposition.

\section{Econometric Methods}

Considering that there is a possibility of the longrun equilibrium relationship among variables used 
in this paper, we use the error correction model (ECM) to estimate the relationship of the variables. Application of the ECM requires that each series in the equation is not stationary and they have a stationary linear combination.

- Unit root test: Augmented Dickey-Fuller (ADF) and the Phillip and Perron (PP) tests are widely used for testing stationarity in macroeconomic data (Ibrahim \& Bashir, 2020).

- Cointegration process: In order to solve the spurious regression problem and violation assumptions of the classical regression model, cointegration analysis was used to examine the long-run relationship between the variables, $(\mathrm{P}$, $\left.\mathrm{E}, \mathrm{M}, \mathrm{P}^{*}\right)$. The short-run dynamics and movement toward equilibrium can be captured with the vector error-correction model (VECM), in which the long-run equilibrium relationship enters into a short-run model (Pesaran \& Shin, 1995).

- The determination of lag length is the important thing to do in the model ARDL, as it is very sensitive to lag length (Bashir \& Babiker, 2021). The determination of optimal lag can be used to set the value of lag based on the test of Akaike information criteria (AIC) and Schwarz information criteria (SIC).

- ARDL model specification: To empirically analyze the long-run relationships and dynamic interactions among the variables of interest, the model has been estimated by using the bounds testing (or autoregressive distributed lag (ARDL) or the cointegration procedure, developed by Pesaran et al., (2001).

This approach involves two stages. In the first stage, the testing for the existence of a long-run equilibrium relationship (cointegration) between observed variables takes place; cointegration among domestic price $(\mathrm{P})$, the nominal exchange rate $(\mathrm{E})$, foreign price $\left(\mathrm{P}^{*}\right)$, and import price index $(\mathrm{M})$ exists if the coefficients $\theta_{1}, \theta_{2}$, and $\theta_{3}$ are different from zero. Specifically, the null hypothesis of the 'nonexistence of the long-run relationship' is tested. Therefore, the null hypothesis, stating that there is no long-run equilibrium relationship, is defined by

$H_{0}: \theta_{1}=\theta_{2}=\theta_{3}=0$,

which is tested against an alternative hypothesis

$H_{1}: \theta_{1} \neq \theta_{2} \neq \theta_{3} \neq 0$,

implying the presence of cointegration.

The relevant statistic is the familiar F-statistic for the joint significance of $\theta_{1}, \theta_{2}$, and $\theta_{3}$.

The bounds testing procedure is based on the $\mathrm{F}$, or Wald-statistics, and is the stage of the ARDL cointegration method such that the relevant statistic to test the null hypothesis is the F-test or the Wald test. Since the asymptotic distribution of these two tests is non-standard, Pesaran et al., (1996) calculated two sets of appropriate critical values for a given significance level.

- Error correction model (ECM): Since tests involving differenced variables can be misspecified and some important information lost if the variables are cointegrated, the errorcorrection term (ECT), which is derived from long-run relationships using the ARDL procedure, is included as an independent variable. Since all the variables are stationary in the system, the short-run adjustment mechanism can be modeled as an ECM. This ECT, lagged by one year, is used in the ECM, together with the current and past differenced fundamentals and other variables that affect the domestic price index and its determinants in the short run.

This procedure of differencing results in a loss of valuable "long-run information" in the data (Maddala, 1992). The theory of cointegration addresses this issue by introducing an errorcorrection (EC) term. The EC term that lagged one 
period (i.e., $E C_{t-1}$ ) integrates short-run dynamics in the long-run of pass-through function. This leads us to the specification of a general error correction model (ECM):

$\Delta P_{t}=\alpha_{0}+\sum_{i=1}^{n} \alpha_{1} \Delta E_{t-1}+\sum_{i=1}^{n} \alpha_{2} \Delta P_{t-1}^{*}+$ $\sum_{i=1}^{n} \alpha_{3} \Delta M_{t-1}+\alpha_{4} E C_{t-1}+\mu_{t}$

where $E C_{t-1}$ is an error correction term that lagged one period.

To determine first-stage pass-through, we estimate an ECT after carrying out Granger causality and testing for cointegration. In other words, to test the pass-through phenomenon, we must incorporate the short-run dynamics into the long-run model, as in the EC modelling below (Pesaran et al., 2001). The error-correction version of the ARDL $(2,2,2)$ model pertaining to the variables in (4) is defined as follows:

$\Delta \ln P_{t}=\beta_{0}+\sum_{i=1}^{n} \beta_{1} \Delta \ln P_{t-i}+$

$\sum_{i=1}^{n} \beta_{2} \Delta \ln E_{t-i}+\sum_{i=1}^{n} \beta_{3} \Delta \ln P^{*}+$

$\sum_{i=1}^{n} \delta_{i} \Delta \ln M_{t-i}+\delta_{1} \ln P_{t-1}+\delta_{2} \ln E_{t-1}+$

$\delta_{3} \ln P_{t-1}^{*}+\delta_{4} \ln M_{t-1}+\mu_{t}$

If $\left(\delta_{1}-\delta_{4}\right)$ are jointly significant, variables are said to be cointegrated.

The short-run effects of pass-through are inferred by the estimates of $\delta_{i}$ '.

- Granger causality test: Statistically, we can detect the direction of causality (cause and effect relationship) when temporally, there is a lead-lag relationship between two variables (Gujarati, 1995, p. 620). The Granger causality test assumes that the information relevant to the prediction of the respective variables TR and $\mathrm{RE}$ is contained solely in the time series data on these variables. The test involves estimating the following regressions:

$$
\begin{aligned}
& P_{t} \\
& =\sum_{i=1}^{n} \alpha_{i} E_{t-i} \\
& +\sum_{j=1}^{n} \beta_{j} P_{t-j}+\mu_{1 t} \\
& \quad E_{t}{ }^{m} \sum_{i=1}^{m} \lambda_{i} E_{t-i}+\sum_{j=1}^{m} \delta_{j} P_{t-j} \\
& +\mu_{2 t}
\end{aligned}
$$

where the disturbances $\mu_{1 t}$ and $\mu_{2 t}$ are uncorrelated.

Equation (7) postulates that the current $\mathrm{P}$ is related to past values of $\mathrm{E}$ itself as well as of $\mathrm{E}$, and (8) postulates a similar behaviour for $E_{t}$.

- Impulse response functions (IRFs) and variance decomposition within a VAR Framework: To investigate the pass-through of exchange rate fluctuations to domestic prices, we will use two different econometric frameworks, which are both based on VAR models. Impulse response function (IRF) traces the effect of a one-time shock to one of the innovations on current and future values of the endogenous. The IRF provides the dynamic responses of the dependent variable to innovations of the variable as well as the innovations of other variables included in the system. It is a process tracing through the effect of a shock (or change in residuals, $\varepsilon_{1}, \varepsilon_{2} \ldots$ ) to each endogenous variable in the system. IRFs essentially map out the dynamic response path of a variable due to a one-period standard deviation shock to another variable. While the impulse response function traces the effects of a shock to one endogenous variable onto the other variables in the VAR, VDC separates the variation in an endogenous variable into the component shocks to the VAR. Thus, the VDC provides information about the relative 
importance of each random innovation in affecting the variables in the VAR. The information contained in the VDCs can be equivalently represented by IRFs. Both are obtained from the moving average representation of the original VAR model (Ibrahim, 2001, p. 135). We use an unrestricted VAR framework, which is in line with McCarthy (2000).

\section{VAR Framework for Estimating Impulse Responses and Variance Decomposition}

The VAR approach models every endogenous variable as a function of lagged values of all endogenous variables in the system. In line with Kiptui et al., (2005, p. 8) and Rowland (2004, p. 16), impulse response functions and VDC estimates are then generated by running an estimate of unrestricted VAR model defined by the following four equations:

$\Delta E=\sum_{i=1}^{k} \beta 11 \Delta E_{t-i}+\sum_{i=1}^{k} \beta 12 \Delta P_{t-i}+$

$\sum_{i=1}^{k} \beta 13 \Delta P_{t-i}^{*}+\sum_{i=1}^{k} \beta 14 \Delta M_{t-i}+\mu_{1 t}$ (9)

$\Delta P=\sum_{i=1}^{k} \beta 21 \Delta E_{t-i}+\sum_{i=1}^{k} \beta 22 \Delta P_{t-i}+$

$\sum_{i=1}^{k} \beta 23 \Delta P_{t-i}^{*}+\sum_{i=1}^{k} \beta 24 \Delta M_{t-i}+\mu_{2 t}(10)$

$\Delta P^{*}=\sum_{i=1}^{k} \beta 31 \Delta E_{t-i}+\sum_{i=1}^{k} \beta 32 \Delta P_{t-i}+$

$\sum_{i=1}^{k} \beta 33 \Delta P_{t-i}^{*}+\sum_{i=1}^{k} \beta 34 \Delta M_{t-i}+\mu_{3 t}(11)$

Table 1: Augmented Dickey-Fuller (ADF) Test
$\Delta M=\sum_{i=1}^{k} \beta 41 \Delta E_{t-i}+\sum_{i=1}^{k} \beta 42 \Delta P_{t-i}+$

$\sum_{i=1}^{k} \beta 43 \Delta P_{t-i}^{*}+\sum_{i=1}^{k} \beta 44 \Delta M_{t-i}+\mu_{4 t}$ (12),

where $\beta_{n m}^{i}$ are parameters to be estimated, $\mathrm{k}$ is the maximum distributed lag length, $\Delta$ is the difference operator, and $\mu_{n t}$ are independently and identically distributed error terms. The time-series data used for the estimations consists of the official nominal exchange rate, E, domestic price proxied by a consumer price index, $\mathrm{P}$, foreign price proxied by consumer price indices of Sudan's major trading partners, $\mathrm{P}^{*}$, and the import price index, $\mathrm{M}$.

\section{EMPIRICAL RESULTS}

\section{Unit Root Tests}

The time-series properties of the variables are first examined. Accordingly, unit root tests are performed to determine the stationarity of the series, as non-stationary series can lead to spurious regression results (Bashir \& Ibrahim, 2020). The ARDL bounds test is based on the assumption that the variables are $\mathrm{I}(0)$ or $\mathrm{I}(1)$. We determine the order of integration of all variables using the unit root tests. The results of the ADF test on the levels and first differences of the variables are presented in Table 1. The lag length was selected using the SIC.

\begin{tabular}{llll|lll}
\hline Variable & Level & & & First Difference & Integrated Order \\
\cline { 2 - 6 } & Intercept & Trend Intercept & Lag & Intercept & Trend intercept & \\
\hline LnE & -0.47 & -1.47 & 2 & -6.61 & -6.69 & I(1) \\
$\ln P^{*}$ & -3.04 & -1.89 & 2 & -3.04 & -3.09 & I $(1)$ \\
Lnm & -3.04 & -1.48 & 2 & -5.58 & -5.56 & I(1) \\
LnP & -1.74 & -1.97 & 2 & -6.87 & -6.78 & I $(1)$ \\
\hline
\end{tabular}

The results of the stationarity tests of ADF show that all variables are non-stationary at the level, but they are stationary at the first difference. It is, therefore, worth concluding that all the variables are integrated of order one. Table 2 reports of PP tests for unit root on both levels and the first difference of the variables. It shows that all the variables are stationary at the first difference, except for foreign price, which was stationary at the level. This means the PP test applied to the first difference of the data series rejects the null hypothesis of non-stationarity for all the variables used in this study. These results 
lead us to test the presence of cointegrations among variables in the model.

Table 2: Phillips-Perron (PP) Test

\begin{tabular}{llllll}
\hline Variable & Level & \multicolumn{4}{c}{ First Difference } \\
\cline { 2 - 6 } & Intercept & Trend Intercept & Intercept & Trend Intercept & Integrated Order \\
\hline $\operatorname{lnE}$ & -0.47 & -1.47 & -6.61 & -6.69 & $\mathrm{I}(1)$ \\
$\ln \mathrm{P}^{*}$ & -4.85 & -1.62 & -1.88 & -3.08 & $\mathrm{I}(0)$ \\
$\ln \mathrm{M}$ & -1.77 & -1.68 & -5.59 & -5.57 & $\mathrm{I}(1)$ \\
$\ln \mathrm{P}$ & -1.81 & -2.06 & -6.84 & -6.75 & $\mathrm{I}(1)$ \\
\hline
\end{tabular}

\section{Lag Length Criteria}

Based on the testing of optimal lag length in Table 3 , it appears that, based on the criteria of AIC and SIC, the optimal lag length is 2 . As the number of annual observations is limited over the period 19782017, the lag length is as small as possible. The reason is that if the lag length is increased, the degree of freedom is decreased, which might then affect the quality of the estimation. This is a reason why the paper chooses two lag lengths for the model, and the best criterion to adopt for the model is AIC.

Table 3: The Lag Length Criteria Analysis

\begin{tabular}{lll}
\hline No. of Lags & AIC & SC \\
\hline 2 & 0.65 & 2.59 \\
3 & 1.00 & 3.67 \\
4 & 0.84 & 4.25 \\
\hline
\end{tabular}

\section{ARDL Bounds for Cointegration}

To empirically analyse the long-run relationships and short-run dynamic interactions among the variables of interest (domestic price, foreign price, nominal exchange rate, and import price index), we apply the ARDL cointegration technique. Testing is performed by Wald statistics in the form of the F- test. If the calculated value of the $F$ statistic is significant (higher than the upper bound), one rejects $H_{0}$ in favor of $H_{1}$, thus showing that the longrun equilibrium relationship between domestic price, nominal exchange rate, foreign price of Sudan's trading partners, and import price index exists.

Table 4: F-Bounds Test

\begin{tabular}{lllll}
\hline Test Statistic & Value & Sign. & I(0) & I(1) \\
\hline F-statistic & 11.13026 & $10 \%$ & 2.37 & 3.2 \\
K & 3 & $5 \%$ & 2.79 & 3.67 \\
& & $2.5 \%$ & 3.15 & 4.08 \\
& & $1 \%$ & 3.65 & 4.66 \\
\hline
\end{tabular}

Since $\mathrm{F}\left(\mathrm{D} \ln \mathrm{P} / \mathrm{D} \ln \mathrm{P}^{*}, \mathrm{D} \operatorname{lnE}, \mathrm{D} \ln \mathrm{M}\right)=11.13$ exceeds the upper bound of the critical value band, at $5 \%$ level given by 2.79 and 3.67, lower and upper bounds, respectively, we can reject the null hypothesis of no long-run relationship between $\mathrm{P}$, $\mathrm{P}^{*}, \mathrm{E}$, and $\mathrm{M}$, irrespective of the order of their integration, I(0) or I(1). The columns headed ' $\mathrm{I}(0)$ ' refer to the lower-band critical values, computed 
when all the k regressors are $\mathrm{I}(0)$; the figures in the columns headed ' $\mathrm{I}(1)$ ' refer to the upper-bound critical values and are computed assuming all the $\mathrm{k}$ regressors are I(1). This means that all the variables move together in the long run.

\section{Error-Correction Model}

Table 5: Error-Correction Result
Once a cointegration relationship is established, an ECM can be estimated to determine the dynamic behavior of ERPT to the domestic price model. We apply the Wald test to measure how close the unrestricted estimates come to satisfying the restrictions under the null hypothesis. The Wald test decisively rejects the null hypothesis, suggesting partial pass-through.

\section{ECM Regression}

Case 2: Restricted Constant and No Trend

\begin{tabular}{lllll}
\hline Variable & Coefficient & Std. Error & t-Statistic & Prob. \\
\hline D(LONFP) & 24.39206 & 6.270636 & 3.889887 & 0.0005 \\
CointEq(-1)* & -1.109554 & 0.140228 & -7.912502 & 0.0000 \\
\hline
\end{tabular}

The coefficient of the error-correction term that represents the proportion through which a long-run disequilibrium in domestic price can be corrected in each year, estimated as -1.109554 , is statistically significant at a 5\% level and correctly negatively signed. This suggests that approximately $110.95 \%$ of total disequilibrium in the domestic price level was being corrected in each year in the country across the study period.

The lagged error-correction term $\left(E C_{t-1}\right)$ coefficient, estimated at -1.109554 (0.140228), carries its correct negative sign and is highly significant in all cases supporting cointegration. It suggests the validity of a long-run equilibrium relationship among the variables in Equation (4) along with a moderate speed of convergence to equilibrium. The estimated value of the coefficient of $\left(E C_{t-1}\right)$ indicates that the speed of adjustment the system corrects its previous period's level of disequilibrium is by $1.1 \%$ a year. The larger the error correction coefficient (in absolute value), the faster is the economy's return to its equilibrium, once shocked (Pesaran \& Pesaran, 1997, p. 307).

\section{Lagrange Multiplier (LM) test for Serial Correlation}

We use the Breusch-Godfrey large sample test for autocorrelated disturbances. It is applicable whether the disturbances follow an $A R_{(\rho)}$ or $M A_{(\rho)}$ process, where $\rho$ can be specified as any positive order. It is also applicable whether or not lagged values of the dependent variable appear among the regressors, for instance, when there is a lagged dependent variable on the right-hand side of the equation. The result indicates that there was evidence of autocorrelation because the p-value is more than $5 \%$.

Table 6: Breusch-Godfrey Serial Correlation LM Test

\begin{tabular}{llll}
\hline F-statistic & 0.089491 & Prob. F (2, 30) & 0.9146 \\
Obs*R-squared & 0.225367 & Prob. Chi-Square (2) & 0.8934 \\
\hline
\end{tabular}

\section{Granger Causality Test}

Granger causality indicates the extent to which current values of Y can be explained by past values of $\mathrm{Y}$ and whether adding lagged values of $\mathrm{X}$ can improve the explanation. $X$ is said to Granger cause $\mathrm{Y}$ if $\mathrm{X}$ helps in the prediction of $\mathrm{Y}$, or if the 
coefficients on the lagged Xs are statistically significant.

We estimate equations 10 and 11 . That is, whether domestic prices Granger cause (effects) nominal exchange rate or vice versa. Since these two variables are stationary and we assume that their residuals are uncorrelated, which are the conditions of the Granger causality test, and the optimum lag is 2, which is the lowest AIC, we can proceed to test Granger causality. We test the null hypothesis by using F-test, and the guidelines for that are the pvalue and the $5 \%$ level of significance.

\section{Table 7: Granger Causality Test}

\begin{tabular}{llll}
\hline Null Hypothesis & Obs. & F-Statistic & Prob. \\
\hline LONE does not Granger Cause LNP & 37 & 0.50212 & 0.6099 \\
LNP does not Granger Cause LONE & & 6.59535 & 0.0040 \\
\hline
\end{tabular}

We can reject the null hypothesis that $\mathrm{P}$ does not Granger cause E because it has strong predictive power, and we accept the alternative hypothesis that $P$ does Granger cause E, but we do not reject the null hypothesis that $\mathrm{E}$ does not cause $\mathrm{P}$ because it has little predictive power and the hypothesis of no Granger causality is easily accepted. Therefore, it appears that Granger causality runs one-way from $P$ to $E$ and not the other way.

Second-stage pass-through: We examine whether exchange rate and import price shocks have an effect on consumer prices using estimates of impulse response functions and variance decomposition. The dynamics of the cointegrated system can be investigated via the VDCs and IRFs.

\section{Impulse Response Functions (IRFs)}

IRFs seek the effects of a shock to the endogenous variable on the other variables in the system; it is a shock to the VAR system. It is a unit shock applied to each variable to see its effect on the VAR system. IRFs identify the responsiveness of the dependent variable in the VAR system when a shock is put to the error term. That is when innovation (impulse, shock, or change) in error term will affect the whole VAR system. The IRFs map out the dynamic response of domestic price to a Cholesky one standard deviation innovation in the nominal exchange. IRFs are used to determine whether exchange rate pass-through exists in Sudan or to assess the impact of exchange rate movements on domestic prices. The results are reported in Figure 1 (a-p). The figure shows the estimated orthogonalized IRFs for consumer price index, foreign price index, and import price index to a one standard deviation innovation in the nominal exchange rate.

An IRF traces the response of an endogenous variable to a change in one of the innovations. Specifically, it traces the effect on current and future values of the endogenous variable of a one standard deviation shock to one of the innovations. There is one IRF for each innovation and each endogenous variable. Because the IRFs are generated from a cointegrated system, a shock in any variable is expected to have a permanent effect on the system, which eventually settles down to a new equilibrium. 
Figure 1 (a-p). Impulse Response Analysis Response to Cholesky One S.D. Innovations

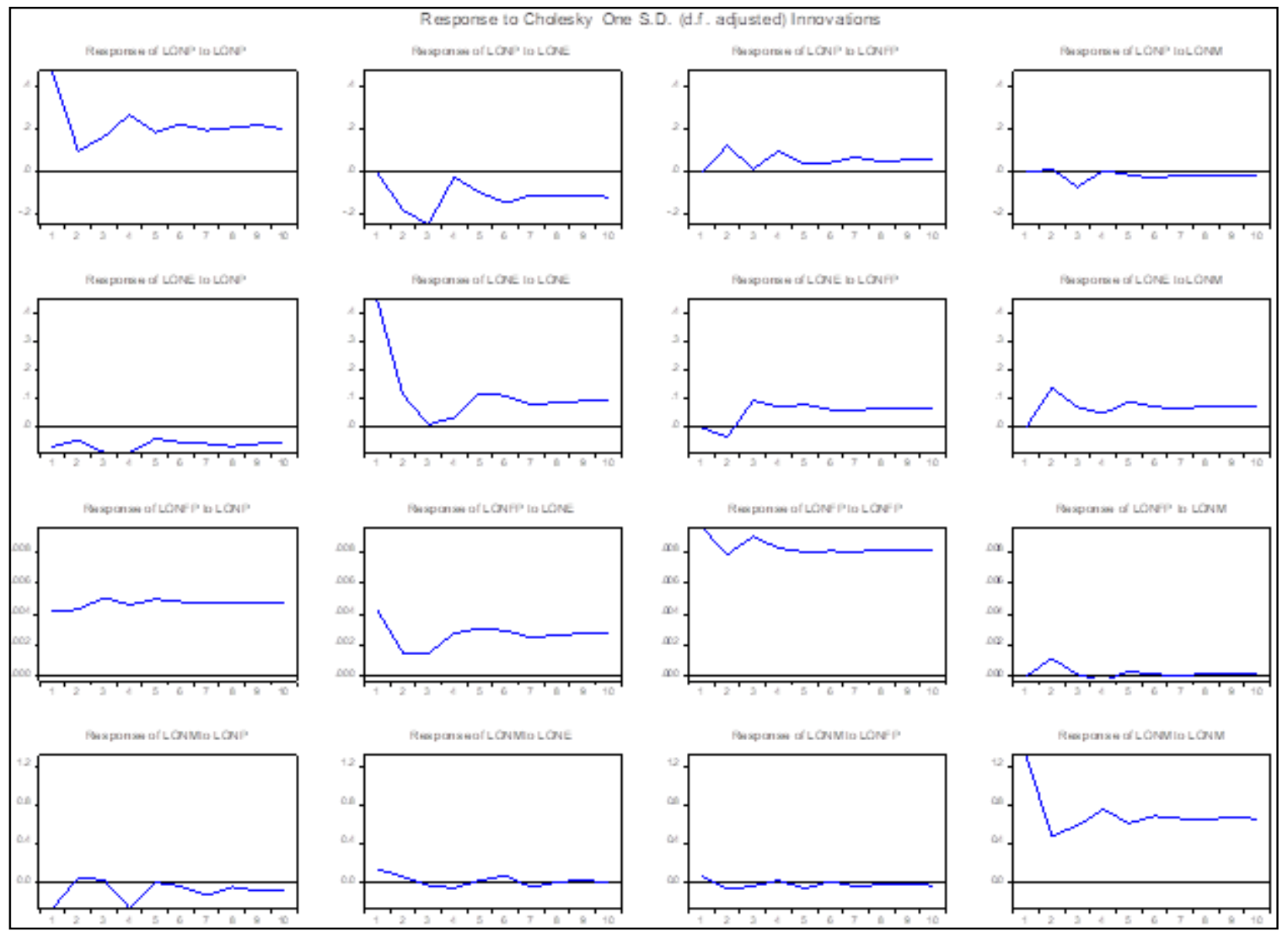

Figure 1(a) shows that one unit of a standard deviation positive shock of domestic price on its own becomes steady 10 years in the future. Figure 1(b): a unit of positive standard deviation shock of exchange rate on domestic price is negative because it is below the zero lines. Figure 1(c): one unit of standard deviation shock of foreign price on domestic price. Figure 1(d): one unit of standard deviation shock of import price index on domestic price. Figure 1(e): one unit of standard deviation shock of domestic price on the exchange rate, which is negative, because it is below the line. Figure $1(f)$ : one unit of standard deviation shock of exchange rate on its own. Figure $1(\mathrm{~g})$ : one unit of standard deviation shock of foreign price on exchange rate. Figure 1(h): one unit of standard deviation shock of import price index on exchange rate. Figure 1(i): one unit of standard deviation shock of domestic price on foreign price. Figure $1(j)$ : one unit of standard deviation shock exchange rate on foreign price. Figure 1(k): one unit of standard deviation shock of foreign price on its own. Figure 1(l): one unit of standard deviation shock of import price index on foreign price.

Figure $1(\mathrm{~m})$ : one unit standard deviation shock of domestic price on import price index. Figure $1(n)$ : one unit of standard deviation shock of exchange rate on import price index. Figure 1(o): one unit of standard deviation shock of foreign price on import price index. Figure 1(p): one unit of standard deviation shock of import price index on its own.

\section{Variance Decompositions (VDCs)}

Decomposes variation in an endogenous variable into the component shocks provided information 
East African Journal of Business and Economics, Volume 3, Issue 1, 2021

Article DOI: https://doi.org/10.37284/eajbe.3.1.394

about the relative importance of random innovations. The VDCs are sensitive to the ordering of the variables. All the variables are stationary in nature because VAR needs stationary variables and also because the lag selection criterion advises us to use 2 lags as optimum.

Table 8: Variance Decompositions

\begin{tabular}{|c|c|c|c|c|c|}
\hline Period & S.E. & LONP & LONE & LONFP & LONM \\
\hline \multicolumn{6}{|c|}{ Variance Decomposition of LONP: } \\
\hline 1 & 0.472082 & 100.0000 & 0.000000 & 0.000000 & 0.000000 \\
\hline 2 & 0.528729 & 83.29626 & 11.06466 & 5.570483 & 0.068595 \\
\hline 3 & 0.610090 & 69.99229 & 24.45725 & 4.237162 & 1.313306 \\
\hline 4 & 0.675427 & 73.17594 & 20.07824 & 5.657320 & 1.088500 \\
\hline 5 & 0.708728 & 73.51414 & 20.00558 & 5.468741 & 1.011544 \\
\hline 6 & 0.759627 & 72.83926 & 21.01234 & 5.108573 & 1.039820 \\
\hline 7 & 0.795420 & 72.57433 & 21.01651 & 5.440275 & 0.968885 \\
\hline 8 & 0.832150 & 72.63388 & 21.11952 & 5.316053 & 0.930541 \\
\hline 9 & 0.869669 & 72.94219 & 20.83589 & 5.336303 & 0.885617 \\
\hline 10 & 0.902607 & 72.79206 & 21.01383 & 5.336595 & 0.857521 \\
\hline \multicolumn{6}{|c|}{ Variance Decomposition of LONE: } \\
\hline 1 & 0.457272 & 2.202346 & 97.79765 & 0.000000 & 0.000000 \\
\hline 2 & 0.495160 & 2.729254 & 88.84842 & 0.508424 & 7.913900 \\
\hline 3 & 0.516847 & 5.406650 & 81.58818 & 3.862291 & 9.142883 \\
\hline 4 & 0.532644 & 7.889229 & 77.24505 & 5.431286 & 9.434437 \\
\hline 5 & 0.560964 & 7.642301 & 74.24757 & 7.005582 & 11.10455 \\
\hline 6 & 0.582378 & 7.925298 & 72.59465 & 7.648226 & 11.83183 \\
\hline 7 & 0.597228 & 8.479464 & 70.77796 & 8.260523 & 12.48206 \\
\hline 8 & 0.615863 & 9.157191 & 68.59275 & 9.056415 & 13.19364 \\
\hline 9 & 0.633119 & 9.521927 & 67.09175 & 9.605945 & 13.78038 \\
\hline 10 & 0.650097 & 9.766475 & 65.74533 & 10.15937 & 14.32883 \\
\hline \multicolumn{6}{|c|}{ Variance Decomposition of LONFP: } \\
\hline 1 & 0.011294 & 13.75204 & 14.38183 & 71.86613 & 0.000000 \\
\hline 2 & 0.014527 & 17.01602 & 9.784355 & 72.59766 & 0.601965 \\
\hline 3 & 0.017875 & 19.23421 & 7.129333 & 73.23613 & 0.400327 \\
\hline 4 & 0.020403 & 19.79836 & 7.298040 & 72.57469 & 0.328905 \\
\hline 5 & 0.022677 & 20.77555 & 7.750311 & 71.19093 & 0.283210 \\
\hline 6 & 0.024714 & 21.25191 & 7.918151 & 70.58940 & 0.240534 \\
\hline 7 & 0.026512 & 21.56429 & 7.757066 & 70.46959 & 0.209057 \\
\hline 8 & 0.028254 & 21.72778 & 7.698743 & 70.38699 & 0.186494 \\
\hline 9 & 0.029897 & 21.91728 & 7.712582 & 70.20236 & 0.167777 \\
\hline 10 & 0.031456 & 22.10176 & 7.706607 & 70.03906 & 0.152575 \\
\hline \multicolumn{6}{|c|}{ Variance Decomposition of LONM: } \\
\hline 1 & 1.350120 & 4.115340 & 1.061525 & 0.190546 & 94.63259 \\
\hline 2 & 1.436906 & 3.740881 & 1.086795 & 0.416746 & 94.75558 \\
\hline 3 & 1.553578 & 3.229982 & 0.978515 & 0.422802 & 95.36870 \\
\hline 4 & 1.749612 & 4.879343 & 0.878534 & 0.348936 & 93.89319 \\
\hline 5 & 1.854435 & 4.343322 & 0.793425 & 0.432417 & 94.43084 \\
\hline 6 & 1.979341 & 3.856920 & 0.819704 & 0.381202 & 94.94217 \\
\hline 7 & 2.092448 & 3.880540 & 0.789322 & 0.382323 & 94.94781 \\
\hline 8 & 2.192233 & 3.587736 & 0.719158 & 0.358149 & 95.33496 \\
\hline 9 & 2.295564 & 3.412604 & 0.670582 & 0.329564 & 95.58725 \\
\hline
\end{tabular}


East African Journal of Business and Economics, Volume 3, Issue 1, 2021

Article DOI: https://doi.org/10.37284/eajbe.3.1.394

\begin{tabular}{llllll}
\hline Period & S.E. & LONP & LONE & LONFP & LONM \\
\hline 10 & 2.389974 & 3.259932 & 0.620000 & 0.324922 & 95.79515 \\
\hline
\end{tabular}

Note: Cholesky Ordering: LONP LONE LONFP LONM

We divide the period into the short and long run. In the short run, that is quarter 3, impulse (or innovation or shock) to domestic price account for $69.99229 \%$ variation of the fluctuations in the domestic price or its own shock. The second shock is the shock to the exchange rate that can cause $24.45725 \%$ fluctuations in domestic price. However, a shock to foreign price can contribute $4.237162 \%$ fluctuations on domestic price, and a shock to import price index can contribute $1.313306 \%$ fluctuations to domestic price. As a result, total fluctuations become $100 \%$.

In the long-run quarter 10 , the impulse to domestic price can contribute $72.79206 \%$ variation of the fluctuations in the domestic price or in its own shock. The second shock is the shock to the exchange rate that can cause $21.01383 \%$ fluctuations in the variance of domestic price. However, a shock to foreign price can contribute $5.336595 \%$ fluctuations on domestic price, and a shock to import price index can contribute $0.857521 \%$ fluctuations to domestic price.

In the short run, that is quarter 3, the impulse to domestic price accounts for $5.406650 \%$ variation of the fluctuations in the exchange rate. The second shock is the shock to the exchange rate that can cause $81.58818 \%$ fluctuations in the exchange rate or its own shock. However, a shock to foreign price can contribute $3.862291 \%$ fluctuations on the exchange rate, and a shock to the import price index can contribute $9.142883 \%$ fluctuations to the exchange rate. As a result, total fluctuations become $100 \%$.

In the long run quarter 10, the impulse to domestic price can contribute $9.766475 \%$ variation of the fluctuations in the exchange rate. The second shock is the shock to the exchange rate that can cause $65.74533 \%$ fluctuations in variance of the exchange rate or in its own shock. However, a shock to foreign price can contribute $10.15937 \%$ fluctuations on the exchange rate, and a shock to the import price index can contribute $14.32883 \%$ fluctuations to domestic price.

In the short-run, that is quarter 3, the impulse to domestic price accounts for $19.2342 \%$ variation of the fluctuations in the foreign price. The second shock is the shock to the exchange rate that can cause $7.129333 \%$ fluctuations in exchange rate to foreign price. However, a shock to foreign price can contribute $73.23613 \%$ fluctuations on foreign price or in its own shock, and a shock to import price index can contribute $0.400327 \%$ fluctuations to foreign price. As a result, total fluctuations become $100 \%$.

In the long-run quarter 10, the impulse to domestic price can contribute $22.10176 \%$ variation of the fluctuations in the foreign price. The second shock is the shock to the exchange rate that can cause $7.706607 \%$ fluctuations in variance of the foreign price. However, a shock to foreign price can contribute $70.03906 \%$ fluctuations on foreign price or in its own shock, and a shock to import price index can contribute $0.152575 \%$ fluctuations to foreign price.

In the short-run, that is quarter 3, the impulse to domestic price account for $3.229982 \%$ variation of the fluctuations in the import price index. The second shock is the shock to the exchange rate that can cause $0.978515 \%$ fluctuations in the exchange rate to the import price index. However, a shock to foreign price can contribute $0.422802 \%$ fluctuations on the import price index, and a shock to the import price index can contribute $95.36870 \%$ fluctuations to the import price index or in its own shock. As a result, total fluctuations become $100 \%$. 
In the long-run quarter 10, the impulse to domestic price can contribute 3.259932 percent variation of the fluctuations in the import price index. The second shock is the shock to the exchange rate that can cause $0.620000 \%$ fluctuation in variance of the import price index. However, a shock to foreign price can contribute $0.324922 \%$ fluctuations on the import price index, and a shock to the import price index can contribute $95.79515 \%$ fluctuations to the import price index or in its own shock.

\section{Stability Tests}

As shown in Figures 2 and 3, the two CUSUM and CUSUMQ statistics are plotted against the breakpoints or break dates. The blue lines lying inside the red lines mean that the model is stable.

\section{Figure 2: Plot of CUSUM}

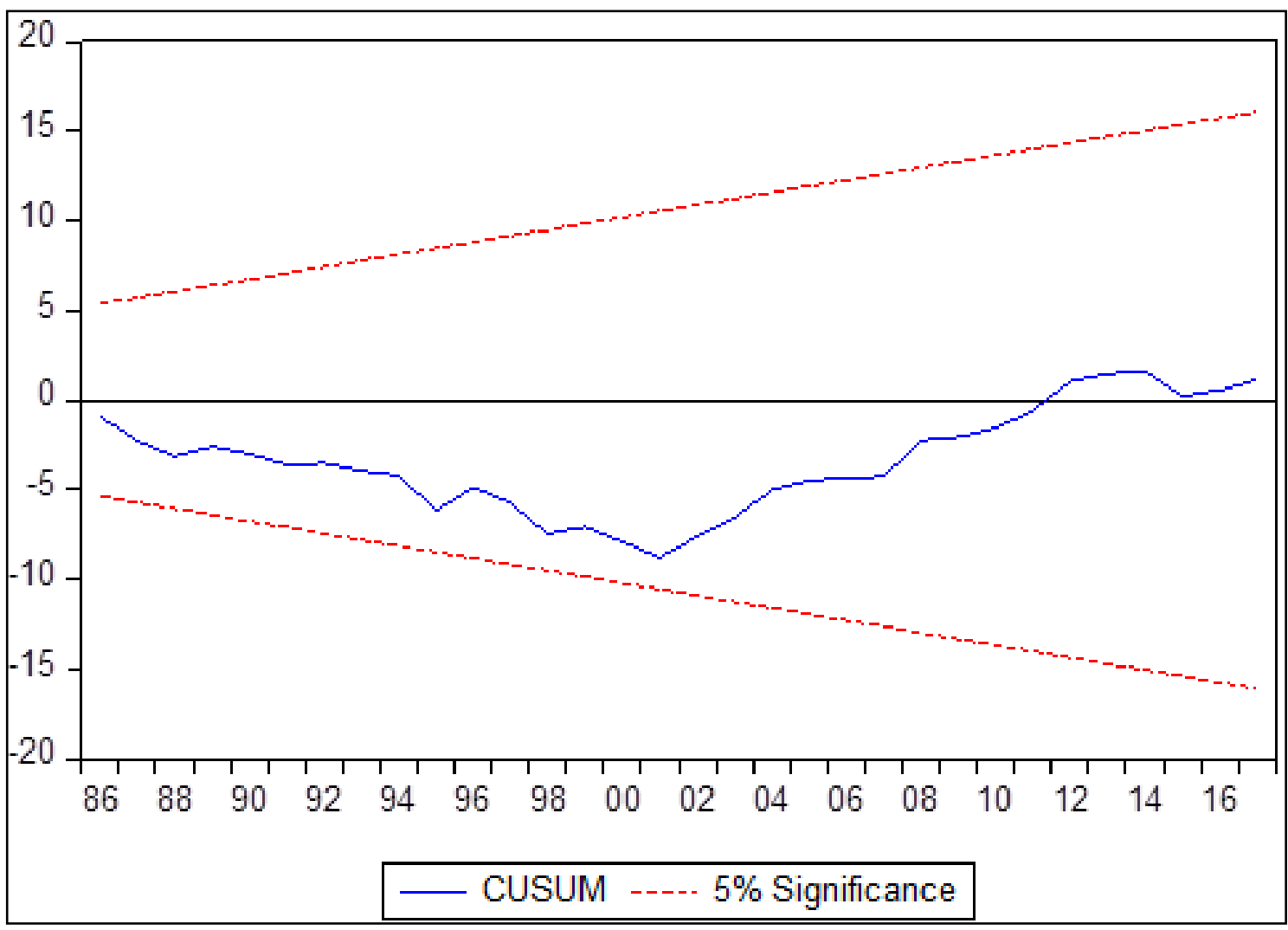


Figure 3: Plot of CUSUMQ

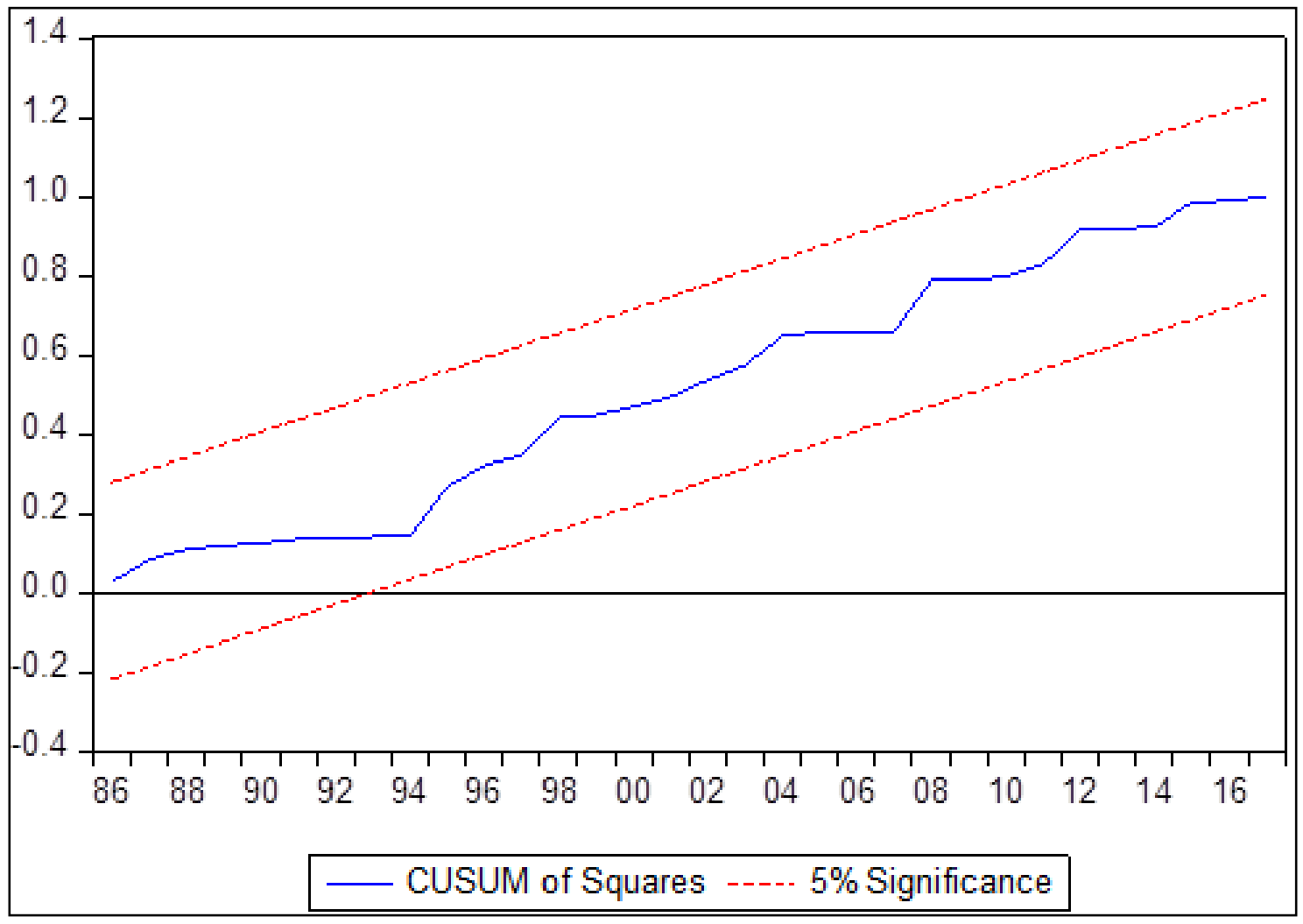

\section{CONCLUSIONS AND RECOMMENDATIONS}

This paper has analysed the long-run ERPT to domestic prices in Sudan based on the LOP, using annual data of 1978-2017. The objective of the paper was to estimate the level of ERPT for Sudan. The degree of ERPT is extremely important when designing monetary policies, particularly in response to an exchange rate shock. In line with most empirical studies of ERPT mentioned earlier, this study concludes that ERPT in Sudan is incomplete. The significant lesson to learn from this research is that the domestic price index is predominantly caused by foreign prices in both the short and long runs, in addition to the import price index and nominal exchange rate.

The study provides some policy recommendations:
- Since inflation is a major source of economic instability, the Central Bank of Sudan may adopt a monetary policy that targets inflation.

- To control inflation, it is important to adopt measures that may strengthen and stabilize the exchange rate system that can protect the domestic economy from foreign and domestic shocks, such as foreign exchange market intervention.

- Since money growth is a key determinant of domestic inflation, it is necessary to reduce the government deficit that will eliminate money printing.

- It is important to activate the open-market operations to strengthen the central bank's effectiveness in liquidity management in the short run. 


\section{REFERENCES}

Amoah, L., \& Meshach, J. A. (2018). Exchange rate pass-through to consumer prices in Ghana: Is there asymmetry?. International Journal of Emerging Markets, 13(1), 162-184. doi:10.1108/ijoem-07-2016-0179.

Bacchetta, P., \& van Wincoop, E. (2003). Why do consumer prices react less than import prices to exchange rates?. Journal of the European Economic Association, 1(2-3), 662-70. doi:10.1162/154247603322391297

Bashir, M. S., \& Babiker, A. (2021). Effects of macroeconomic variables on gross domestic product in Saudi Arabia using ARDL model 1993-2019. Journal of Economics and Administrative Sciences, 27, 553-570. doi:10.33095/jeas.v27i126.2124.

Bashir, M. S., \& Ibrahim, A. A. (2020). Effects of macroeconomic variables on bank credit in Saudi Arabia: An ARDL bounds testing approach to cointegration. Asian Journal of Economics Business and Accounting, 19(2), 112. doi: 10.9734/AJEBA/2020/v19i230298.

Campa, J., \& Goldberg, L. (2005). Exchange rate pass-through into import prices. Review of Economics and Statistics, 87(4), 679-690. doi: 10.1162/003465305775098189.

Dwyer, J., Kent, C., \& Pease, A. (1994). Exchange rate pass-through: Testing the small country assumption for Australia. Economic Record, 70(211), 408-423. doi:10.1111/J.14754932.1994.TB01859.X

Goldberg, P. K. (1995). Product differentiation and oligopoly in international markets: The case of the US automobile industry. Econometrica, 63(4), 891-951. doi:10.2307/2171803.

Goldberg, P. K., \& Knetter, M. (1997). Goods prices and exchange rates: What have we learned?. Journal of Economic Literature, 35, 1243-1272.

Gujarati, D. N. (1995). Basic econometrics, (3 ${ }^{\text {rd }}$ Edition.). McGraw-Hill Book Co., Singapore.

Helmy, O., Fayed, M., \& Hussien, K. (2018). Exchange rate pass-through to inflation in Egypt: a structural VAR approach. Review of Economics and Political Science, 3(2), 2-19. doi:10.1108/REPS-07-2018-001.

Hussain, M. N., \& Thirlwall, A. P. (1984). The IMF supply side approach to devaluation: An assessment with reference to Sudan. Oxford Bulletin of Economics and Statistics, 46(2), 145$167 . \quad$ Retrieved from https://ideas.repec.org/a/bla/obuest/v46y1984i2 p145-67.html.

Ibrahim, A. A. \& Bashir, M. S. (2020). Long-run and short-run determinants of the real exchange rate in Sudan: An autoregressive distributed lag model. Economic Researcher Review, 8 (13), 310-338. Retrieved from https://www.asjp.cerist.dz/en/PresentationRevu e/85

Ibrahim, A. A. (2001). The effects of exchange rate changes on trade balance in Sudan [Unpublished PhD thesis]. University Putra Malaysia.

International Monetary Fund. (1980-2018). Directions of Trade Statistics. [Data set], Retrieved from https://data.imf.org/?sk=9D6028D4-F14A464C-A2F2-59B2CD424B85

International Monetary Fund. (1980-2018). International Financial Statistics. [Data set]. Retrieved from https://data.imf.org/?sk=4c514d48-b6ba-49ed8ab9-52b0c1a0179b

Isnowati, S., \& Setiawan, M. B. (2017). Exchange rate pass-through to import prices in Indonesia: 
Evidence post free floating exchange rate. Pesaran, M. H., Shin, Y., \& Smith, R. J. (2001).

International Journal of Economics and Financial Issues, 7(1), 323-328.

Jasová, M., Moessner, R., \& Takáts, E. (2016). Exchange rate pass-through: What has changed since the crisis?. BIS Working Papers No. 583, Bank for International Settlements. Retrieved from

https://ideas.repec.org/p/bis/biswps/583.html.

Kiptui, M., Ndolo, D., \& Kaminchia, S. (2005). Exchange rate pass-through: To what extent do exchange rate fluctuations affect import prices and inflation in Kenya?, Policy Discussion Paper No. 1. Central Bank of Kenya.

Lott, Z. (2013). Exchange rate pass-through on EBay. Department of Economics, Stanford University.

Maddala, G. S. (1992). Introduction to econometrics, ( $2^{\text {nd }}$ ed.). Englewood Cliffs, Prentice Hall, Inc.

McCarthy, J. (2000). Pass-through of exchange rates and import prices to domestic inflation in some industrialized economies. Staff reports 111. Federal Reserve Bank of New York.

Pesaran, M. H., \& Y. Shin (1995). An autoregressive distributed lag modelling approach to Cointegration analysis. DAE Working Paper No. 9514. Department of Applied Economics, University of Cambridge.

Pesaran, M. H., Shin, Y., \& Smith, R. J. (1996). Testing for the existence of a long-run relationship. DAE Working Paper No. 9622. Department of Applied Economics, University of Cambridge.

Pesaran, M. H., \& Pesaran, B. (1997). Working with Microfit 4.0 interactive econometric analysis. Oxford University Press.
Bounds testing approaches to the analysis of level relationships. Journal of Applied Econometrics, 16(3), 289-326. doi.org/10.1002/jae.616

Pham, V. (2019). Exchange rate pass-through into inflation in Vietnam: Evidence from VAR model. Journal of Economics \& Development, 21(2), 144-155. doi:10.1108/JED-07-20190013.

Rowland, P. (2004). Exchange rate pass-through to domestic prices: the case of Colombia. Ensayos Sobre Politica Economica, 47, 106-125. doi:10.32468/Espe.4703

Takhtamanova, Y. F. (2010), Understanding change in exchange rate pass-through. Journal of Macroeconomics, 32(4), 1118-1130.

Yol, M. A. (February 2010). Determinants of inflation in Sudan: An empirical analysis. Working Paper No. 16. Central Bank of Sudan. 